\title{
ICT in Teacher Education: Developing Key Competencies in Face-to-Face and Distance Learning
}

\author{
Ana A. Carvalho \\ University of Minho, Campus de Gualtar, \\ 4710-057 Braga, Portugal \\ aac@ie.uminho.pt
}

\begin{abstract}
This paper reports the training of 56 Teachers in ICT and Education Course. This course included one week face-to-face and seven weeks in distance learning. Students developed several ICT competencies during theses weeks, reporting its use in their classes. A characterization of the subjects' digital literacy is presented, as well as their participation in chat sessions and in the forum, which were not mandatory but highly recommended. The majority of students did not participate in the synchronous and asynchronous communication facilities. However, those that participated in the chat sessions and forum debates completed all tasks and assignments. The students recognized the importance of learning about ICT and how it changed their teaching methods.
\end{abstract}

Keywords: ICT, Key Competencies, WebQuest, Treasure Hunt, Concept maps, Podcast.

\section{Introduction}

This paper presents the challenge of motivating teachers to use and reflect about ICT, particularly Web 2.0 tools in teaching and learning, during a face to face week and seven weeks of online learning. The key competencies emphasized within this course are particularly related to ICT but also to the three broad categories identified by the DeSeCo Project's conceptual framework for key competencies: use tools interactively, interact in heterogeneous groups, and act autonomously [1]. The UNESCO's project "ICT Competency Standards for Teachers" stressed that schools and classrooms "must have teachers who are equipped with technology resources and skills and who can effectively teach the necessary subject matter content while incorporating technology concepts and skills" (p. 1) [2].

The ICT and Education Course belongs to a training program -“Online Teaching and Learning \& Professional Development of Teachers in the Republic of the Maldives” - supported by UNICEF Maldives and developed by the University of Minho, in Portugal, during the 2008 and 2009 academic years. It included four compulsory courses and three optional courses (Table 1). The compulsory courses lasted 80 hours, during eight weeks and the optional courses 36 hours during three weeks. All courses used the LMS (Learning Management System) Blackboard and were distance learning courses, but Teaching/ Teacher Education, Supervision and Monitoring, and ICT 
and Education courses had a face to face week in Male, Maldives, in May and seven weeks online. The face to face week was a requirement of UNICEF Maldives. The full program lasted 408 hours.

Eighteen Portuguese lecturers participated in this training program along with fiftysix Maldivian' teachers, who needed to update their knowledge about teaching and ICT. The language of the program was English, a foreign language for both lecturers and students.

Table 1. Training Program Structure

\begin{tabular}{|c|c|}
\hline $\begin{array}{l}\text { Compulsory and Optional Course } \\
\text { Units }\end{array}$ & Course Units \\
\hline $\begin{array}{l}\text { Compulsory Course Units } \\
\text { Duration: } 80 \text { hours each at } \\
\text { 10hrs/week }\end{array}$ & $\begin{array}{l}\text {-Teaching/ Teacher Education } \\
\text {-Supervision and Monitoring } \\
\text {-ICT and Education } \\
\text {-Online and Distance Education }\end{array}$ \\
\hline \multirow{3}{*}{$\begin{array}{l}\text { Optional Course Units } \\
\text { Duration: } 36 \text { hours each at } \\
12 \mathrm{hrs} / \text { week }\end{array}$} & $\begin{array}{l}\text {-School Administration } \\
\text {-School Management }\end{array}$ \\
\hline & $\begin{array}{l}\text {-Change Management in Education } \\
\text {-Educational Management and } \\
\text { Leadership }\end{array}$ \\
\hline & $\begin{array}{l}\text {-Behaviour Management } \\
\text {-Special Educational Needs }\end{array}$ \\
\hline
\end{tabular}

During the five face to face sessions in Male, students attended three two-hour lectures daily. The first went, from $8 \mathrm{am}$ to $10 \mathrm{am}$, the second from $10.30 \mathrm{am}$ to $12.30 \mathrm{pm}$, and the third from $2 \mathrm{pm}$ to $4 \mathrm{pm}$.

At the University of Minho we suggested dividing the students into three groups thus giving them more personalized feedback and orientation during the activities. When in Male, we realized that this purpose was fundamental, not only to ICT as each student had access to a computer, but also to the other two courses as most students lack technical and scientific knowledge.

\section{ICT and Education Course}

The ICT and Education Course had four learning outcomes: assess website quality, use Web tools (blogs, podcasts, and Google pages), distinguish collaboration from cooperation and the implications for students' group work, and select and use WebQuests and Treasure Hunts with students. The syllabus attempted to familiarize students with technical words, tools, and pedagogical uses of resources available online. Concepts such as the Internet, the Web, Web 2.0 tools, social networking, connectivism, synchronous and asynchronous communication, collaboration and cooperation, searching the Web, criteria for evaluating websites, quoting and plagiarism, editing online, concept maps, WebQuest, and Treasure Hunt were approached and their pedagogical benefits discussed. 
The main focus of this course unit was to motivate students to use and integrate ICT appropriately in the classes they teach. Theoretical aspects were discussed in the forum but the main purpose of all discussions was a reflection about its use in teaching contexts. We intended that our students applied the tools (blogs, podcasts, concept maps, etc.) and activities (WebQuest, Treasure Hunt) with their own students reporting their difficulties, enjoyments and reflections regarding its use.

We also intended that students work in groups in their own school to experience collaborative and cooperative activities.

\subsection{Course Structure}

As mentioned previously, this course had a face to face week in May 2008, 2 hours per day with each group of students (Table 2). This option proved to be appropriate for students as each one had computer access; however it was somewhat tiring for the tutor. She had six hours per day every day during the week, from Sunday to Thursday.

The other 7 weeks online only took place in March and April of the following year. Every week possessed the same structure: a new topic was introduced with readings and activities, there were two chat sessions at $8 \mathrm{pm}$ for students (and at $4 \mathrm{pm}$ for the tutor). They also had one or two threads in the forum helping them to reflect about the readings and activities of the week.

Table 2. ICT and Education Course Structure

\begin{tabular}{ll}
\hline Course duration & Course structure \\
\hline Face to face week & -Participants characterization \\
[May 2008] & -Introduction to ICT \\
& -Introduction to Blackboard facilities \\
& -Create a blog and post comments to their \\
colleagues & -Create a podcast (audio) \\
& -New literacies. \\
& Each week: \\
7 weeks online & -A new topic was introduced \\
LMS: Blackboard & -2 chat sessions (1 hour each) \\
[March-April 2009] & -Forum (1 or 2 threads) \\
\hline
\end{tabular}

Not all of the Maldivian teachers had Internet access at home therefore; they had to go to school at night if they wished to participate in the chat sessions. The time of the chat sessions was based on students' preference.

\section{Students' ICT Characterization}

During the first face to face session, students filled out a questionnaire regarding digital literacy. It included information about their gender and age, followed by eight questions: (1) their knowledge about online tools or resources , (2) if they had a blog, podcast or website; (3) if they used some of the tools or resources listed in item 1 ; (4) 
if their school had a website; (5) frequency of access to Internet resources with their students; (6) if the teachers publish their students' work online; and finally if they have a computer at home with Internet connection.

The questionnaire was filled in by 56 students, 32 male and 24 female. Most of the students (39) were aged between 31 to 40 years old, 12 between 20 and 30, and 5 were older than 41 . They were very interested in participating in this training program and were selected by the Maldivian Education Department. They were from different atolls, but a small group of two to five students belonged to the same atoll to support each other and to work collaboratively.

All of them knew Google, 48\% YouTube, 34\% blog, 27\% Movie Maker, 20\% Wiki and Flickr, 16\% hi5, 9\% Podcast, 7\% WebQuest, 5\% Treasure Hunt, and one individual knew Second Life and Delicious (Table 3). These results showed that the students required an ICT update.

Table 3. ICT tools or resources known by students $(n=56)$

\begin{tabular}{lcc}
\hline ICT tools or Resources & $\mathrm{f}$ & $\%$ \\
\hline Google & 56 & 100 \\
Blog & 19 & 34 \\
Podcast & 5 & 9 \\
Wiki & 11 & 20 \\
YouTube & 27 & 48 \\
Flickr & 11 & 20 \\
Delicious & 1 & 2 \\
Hi5 & 9 & 16 \\
Movie Maker & 15 & 27 \\
WebQuest & 4 & 7 \\
Treasure Hunt & 3 & 5 \\
Second Life & 1 & 2 \\
\hline
\end{tabular}

When inquired if they had blog, podcast or website, only a few answered positively (Table 4). Only $11 \%$ had a blog, $9 \%$ a website, and $5 \%$ a podcast.

Table 4. Students ' presence online $(n=56)$

\begin{tabular}{lcc}
\hline Web 2.0 tools and website & f & $\%$ \\
\hline Blog & 6 & 11 \\
Podcast & 3 & 5 \\
Website & 5 & 9 \\
\hline
\end{tabular}

When asked if they used the tools or resources presented in table 3 with their students, only 30 participants answered affirmatively (Table 5). From those (30), almost all of them (29) use Google, 4 students WebQuests, 2 blogs, and one YouTube and Treasure Hunt. These results evidenced the need to update these teachers. This need to update teachers to ICT competencies is supported by UNESCO [2] and by authors such as Richardson [3] or Siemens [4]. 
Table 5. Tools and resources used in classes $(n=30)$

\begin{tabular}{lcc}
\hline $\begin{array}{l}\text { Tools and resources used in } \\
\text { class }\end{array}$ & $\mathrm{f}$ & $\%$ \\
\hline Google & 29 & 97 \\
WebQuest & 4 & 13 \\
Blog & 2 & 7 \\
Treasure Hunt & 1 & 3 \\
YouTube & 1 & 3 \\
\hline
\end{tabular}

With regard to a school website, 22 of the participants indicated that their school had one. A large group of teachers $(46 \%)$ rarely used the Internet with their students, and 11 never did (Table 6). Only 7 used the Internet daily, 8 weekly, and 4 monthly. Later on they explained that some schools had a computer lab but most of them only contained one or two computers for staff use. The government was sensitive to this problem and was making an effort to update the Internet connection and buy computers for the schools. This situation occurred in other countries such as Malaysia reported by Kader [5] and Bhutan by Won [6].

Table 6. Using Internet resources with students $(n=56)$

\begin{tabular}{lcc}
\hline $\begin{array}{l}\text { Frequency of Internet } \\
\text { with students }\end{array}$ & f & $\%$ \\
\hline Daily & 7 & 13 \\
Weekly & 8 & 14 \\
Monthly & 4 & 7 \\
Rarely & 26 & 46 \\
Never & 11 & 20 \\
\hline
\end{tabular}

Only 5 participants published their students' work online. Finally, we asked them if they had a computer at home with an Internet connection (Table 7) because this was a prerequisite for the courses online.

As we may verify in Table 7,93\% of the participants had a computer at home, but only $71 \%$ had an Internet connection. Some of them had to use school facilities during the course, particularly for the chat sessions at late evening.

Table 7. Computer and Internet connection at home $(n=56)$

\begin{tabular}{lcc}
\hline $\begin{array}{l}\text { Computer and Internet } \\
\text { connection at home }\end{array}$ & $\mathrm{f}$ & $\%$ \\
\hline $\begin{array}{l}\text { Computer } \\
\text { Internet connection }\end{array}$ & 52 & 93 \\
\hline
\end{tabular}

\section{The Face to Face Week}

The students completed a questionnaire regarding Digital Literacy. They were introduced to the ICT and Education course and its learning outcomes. Particular emphasis 
had been placed on the weekly goals that intended to create a new framework about learning methods and Web 2.0 tools, such as blogs and podcast. Students had to distinguish Internet and World Wide Web, create their own blog and podcast, and reflect about the implications of new literacies for learning (Table 8). Simultaneously, it was very important that they felt comfortable and familiar with the LMS Blackboard thus, every day they had something to do to remember its functionalities. The technical preparation for distance learning as well as the comprehension of the role of a distance learner is very important. Mason [7] states:

"Those who have poor study habits, lack self-discipline or motivation, have been educationally disadvantaged, or are driven almost solely by extrinsic reasons for wanting a degree, tend to find the student-centred pedagogy bewildering, too demanding, or too much hard work. (...) Students do need a gradual process of learning to be self-directed. They need training and practice in ICT skills such as research, analysis and management of web-based resources; they need a student-friendly online environment that encourages and rewards interaction. They also need supportive tutoring to help them adapt their study patterns from linear working through textbooks and lecture notes to interactive engagement with ideas, resources and other students" (p. 65-66).

Table 8. Contents of the first week

\begin{tabular}{ll}
\hline Session & First week contents \\
\hline 1 & $\begin{array}{l}\text { Internet and World Wide Web. } \\
\text { Blackboard: an introduction. }\end{array}$ \\
2 & $\begin{array}{l}\text { Blog: features, and learning implications. Create } \\
\text { a blog. } \\
\text { Blackboard: Chat. }\end{array}$ \\
3 & $\begin{array}{l}\text { Podcast: characteristics, and implications in } \\
\text { learning. Create a podcast. }\end{array}$ \\
& Blackboard: Discussion board (forum). \\
4 & $\begin{array}{l}\text { Record a text in Audacity and save it as mp3. } \\
\text { Post it in Podomatic. Insert a picture. }\end{array}$ \\
& $\begin{array}{l}\text { New literacies and its effect in learning. } \\
\text { Blackboard: upload a file to Discussion Board, } \\
\text { Digital Dropbox, and Group Pages. }\end{array}$ \\
\end{tabular}

The students were very interested. For some, everything was new and a few were unable to distinguish an e-mail address from a URL. One of the problems that occurred when they created a blog was to remember its URL and password. They were able to upload a picture, embed a video, and incorporate a link into blog posts. I used Richardson's [3] and Siemens' [8] ideas about the use of blogs in educational contexts. "Blogging is a genre that engages students and adults in a process of thinking in words, not simply an accounting of the day's events and feelings" (p. 20) [3]. It is important that blogs be used as places of critical thinking and analytical writing and 
reflection. They can be used as class portals, e-portfolios, collaborative space, etc. Richardson [3] also considered that there is no better way to understand the impact of the Read/Write Web than by becoming a part of it. This was one of the main purposes of the week.

The podcasts were introduced, mentioning several ways to use them in education. For example, to record local stories or historical events, to challenge students to do a group project, to invite students to report their group work, to summarize content, and so on. The podcasts created by the teacher or the students have a good impact on listeners, as reported by studies conducted by Carvalho et al. [9], [10], Salmon et al. [11] and Frydenberg [12]. Students like hearing their teachers' voice as stated by Durbridge [13], Richardson [3] and Carvalho et al. [14]. All students created their first podcast using Podomatic. In the following session, the software Audacity was introduced and students recorded their episode. Next, they uploaded it to Podomatic. In the class, it was referred again "that's what the Read/Write Web is all about: being able to share what you create with others" (p. 118) [3].

During the last face to face session, we approached the new literacies as a concluding session of the topics focused. We stressed that for more than a hundred years we have defined being literate as being able to read and to write, although those core abilities are central to learning, they are no longer sufficient to ensure understanding [3]. Writing is no longer limited to text, we can use words, audio, video, and photography. It is difficult to deny that more and more we have become a multimedia society. We can combine many forms of writing into a process of "rip, mix, and learn", taking a piece of content here and another there, combining it to produce powerful text and nontext messages and interpretations [15]. Readers of the Web content must learn to be active consumers instead of just passively accepting it as legitimate. The classroom of the Read/Write Web is one seamless transfer of information, of collaborative, individualized learning, of active participation by all class members. It is marked by the continuous process of creating and sharing content with wide audiences. Our students are learning that their voices matter, that people are reading and responding, and that their ideas count. Moreover, when writing, for example in the blog, "ideas are presented as the starting point for a dialogue, not the ending point" [8]. By inviting students to become active participants in their own learning, we teach them how to be active participants in their lives and future careers. Teachers will have to see themselves as connectors, of content and of people. To use Web 2.0 tools effectively, educators must learn to use them effectively. They need to become bloggers and podcasters, to use other social tools effectively with their students. Teachers need to think of themselves as coaches who model the skills that students need to be successful and motivate them to strive for excellence.

Students were invited to keep their blogs and podcasts updated, until the next distance learning sessions of this course.

\section{Learning ICT Online}

The second week of the course started in March 2009. Every Saturday an announcement regarding the weekly activities was posted on the LMS and was sent by email to students via Blackboard. It included the topic that would be learned, the readings, the 
chat sessions timetable, the deadline for answering the forum questions, and students were reminded to read the week's guidelines in Course Documents. If they preferred, they could listen to a podcast with the announcements of the week. As they were familiar with the tutor, listening to her voice could have a motivational effect on them, as mentioned previously [3], [13], [14], [16]. A slide presentation and the readings were also available in the Course Documents.

The second week was devoted to reviewing the concepts approached during the first week and to debate Prensky's paper about Digital Wisdom [17].

The third week focused on WebQuest which was also the topic of the first assignment. Students had to select a WebQuest and analyse it, based on a grid developed by the tutor. Then, they invited their students to solve it in class and they had to report their reactions - if they liked it, if they solved it autonomously, if they learned the topic addressed in the WebQuest, and finally what were the advantages of using the WebQuest in learning. As during the chat some students mentioned that they did not have Internet connection in the school or computers in class, they only responded to the last item.

In her assignment one student wrote:

"It was really a great experience. They [the students] were very much involved in the activity. Even the two groups had a competition. Each group wanted to complete the task before the other. I found that the students enjoyed the webquest very much and they wanted to do more tasks. Also, I found that they were solving problems eagerly. I believe that if we could use such activities and facilities in our classrooms more often, the pupils would be more motivated".

Another student said:

"Solving WebQuests has many advantages for students because it includes higher level thinking, questions to be answered or solved and problems which are related to real life. To solve a WebQuest, students have to work in pairs or group, which promotes their social skills. In my opinion solving a WebQuest has the following advantages: WQ encourages critical thinking and cooperative learning, active learning, students have to make sense of what they are reading, it motivates students, and it improves students' synthesis, analysis, and evaluation skills".

The fourth week was about Treasure Hunt and students had to compare its structure with that of WebQuest. They were invited to create a Treasure Hunt in their own blog. They could send the tutor their Treasure Hunt before editing it online. After publishing it on the Web they invited their students to solve it.

During the fifth week they had to evaluate website quality, based on Alexander and Tate's criteria [18],Web Site Evaluation [19], 23 Quality Criteria [20], the Ten C's for Evaluating Internet Resources [21].

The sixth week focused on meaningful learning and modelling with technology according to David Jonassen [22]. Some audio podcasts containing excerpts from the book were available on the Blackboard, particularly for students that did not have access to the book. A native speaker was invited to read the book excerpts.

In the following week, the topic was concept maps and students had to read the chapters related to it in Jonassen's book [22] or listen to the podcasts. Students had to install Cmap tools and create a concept map; afterwards they should use it with their students. A tutorial about Cmap Tools was available for them. The second assignment was a report about the use of concepts maps by teachers or by their students in the classroom. 
During the last week, the connectivism purposed by George Siemens [23], [24] and Stephen Downes [25] was introduced. Two important concepts in the digital age were distinguished: quoting and plagiarism, showing how one cites references. Finally, the collaborative and cooperative learning and its implications in group work was stressed.

The students had a final exam in October in Male.

\subsection{Students' Participation in the Chat Sessions and Forums}

Students' participation in the two weekly sessions and in the forum threads was not mandatory but highly recommended. Only a small group of students participated in the forums. In all fourteen chat sessions the number of participants ranged from 4 to 15. We realized that the students that participated in the chat sessions could clarify their doubts. Most of the time, they asked for questions about the topic under discussion. Some were checking what they knew regarding the subject at hand while others were learning it as they did not read the proposed d reading material.

The seven forums included nine threads. The number of respondents ranged from 12 to 14 . They had time to think about their answer, and for each reply the tutor wrote a constructive comment.

At the end of the course, after submitting their assignments, the students were invited to complete a course unit evaluation questionnaire, but only six did so. Half of them participated in the forum threads and chat sessions. Those that did not participate provided different reasons. One reported technical problems in accessing the Blackboard platform and he did not have Internet access at home. The student wrote: "During the ICT course I had a dial up connection at School, its speed is $21 \mathrm{kbs}$. I travelled to nearest TRC [Teacher Resource Centre] but uploading and downloading materials is expensive and only during the daytime. Night travelling is not possible and the next day cannot report to school if I do so". Another student did not participate in the forums or in the chat sessions, because "I was too busy with my job due to certain unavoidable reasons. I wanted to participate in the forums and chat but I could not. But I read the chat recordings". The third one answered the forums threads but she could not participate in the chat sessions, she said: "I completed all the forum work but it was very difficult for me to participate in the chat sessions as I was in Australia at the time. The time for the chat session for us was 2 o' clock in the morning. Anyway, I participated in many chat sessions too".

A student commented the following strategy: "you [the tutor] had listed the list of participants for the chat sessions and forums. That was one of the best things you did to get the participants to pay attention to the course unit".

\section{Final Remarks}

Some particular situations arose during the course due to the students' lack of ICT key competencies and the failure to read the recommended texts. Sometimes in the chat sessions some students were writing in Dhivehi to help each other, particularly in the first sessions. Some of them did not read the papers before the chat and most of the time the tutor was explaining the subject rather than clarifying their doubts. Due to 
this fact, one student wrote: "the chat session was not much useful as many of the participants were out of the topic".

When Cmap Tools were introduced, they mentioned having some difficulties in installing it. So, during the chat session I was explaining what they should do. Then, the download time generated a sort of race. It became fun because some of them downloaded faster than others, and they were providing details about the download percentage.

During this course unit some students were in Australia taking another course and there was a 6 hour difference, so at 8pm (chat session) it was $2 \mathrm{am}$ in Australia. Some of those were complaining about the time of the chat sessions.

The University sent to Maldives twenty books per course. Some students did not get the Jonassen's book, but "we managed to get the copy of the units that u recommended for us to read from another school". The podcasts about the book were intended to help those that had difficulties in getting it. A student that listened to podcasts indicated that he listened to the podcasts about the book, "because I did not get the book, I love reading rather than listening". One student that read the book also listened to the podcasts. She commented "I preferred listening to the podcasts about the book". This student is the only one that indicated that in other distance learning courses she would like to hear the teacher's voice giving advice or guidelines, all other respondents preferred reading the guidelines. All others preferred to get written feedback instead of audio. In a study conducted in Portugal [10] the students liked receiving audio feedback. The different reaction of the Maldivian students may be justified by the fact that the tutor and the students were not native speakers therefore, reading a text would probably be easier to understand.

On a five points scale ranging from poor to excellent, students considered very good or excellent: the relevance of the course unit contents, the organization of the course in modules (one per week), the guidelines for the week, the adequacy of the assignments compared to the aims of the course unit, and the support from the teacher. They mentioned that the course unit contents were useful for their job.

The students were asked to give a free comment about the ICT in Education course. Their comments were positive and showed the impact of this training in their professional life: "The course unit was very interesting and we learned a lot which can be used in our educational system". Another student wrote: "I have learnt how to use WebQuests and Blogs for the teaching purposes and in the capacity of a teachers' educator as well. ICT is something without which we teachers cannot just teach these days". One student recognized not only the importance of the course but also the need to update the equipment and the Internet access in schools: "ICT course is a very useful one. I learned a lot from this course. I introduced some of the components to my colleagues and they also found them very useful. For me, the main difficulty is that most of our students do not have Internet access. We are unable to use (in the class) what we have learned from this course but gradually parents are also becoming aware of the importance of the Internet and we can use this in the class very soon. It is also important to note that our classrooms are not ICT friendly classrooms. However, we are using the Teacher Resource Centre to teach some lessons using the smart board. Anyway, I found that this course is very useful to me". This initiative of training teachers first and updating the system after is much better than the other way around. Finally, one last comment to synthesize everything: "The ICT course unit was 
the most useful unit for my personal and professional development during this course. As you can understand, during the face to face week, many of us were not able to explain much about podcasts, blogs, WebQuest, Treasure Hunt, concept maps, web tools etc. But after completing this unit, now we are the first batch of people who can explain to many of the Maldivian teachers and students these useful things for the teaching and learning process of our students and teachers".

We may conclude with John's and Wheeler's [26] words, now these "teachers hold the key to future developments" (p. 15) and with their commitment to ICT use, many of the opportunities to innovate and transform education and learning will be seized.

\section{References}

1. OECD: The Definition and Selection of Key Competencies. Executive Summary (2005), http: / /www. oecd.org/dataoecd/47/61/35070367.pdf

2. UNESCO: ICT Competency Standards for Teachers. UNESCO, Paris (2008)

3. Richardson, W.: Blogs, Wikis, Podcasts, and Other Powerful Web Tools for Classrooms. Corwin Press, Thousand Oaks (2006)

4. Siemens, G.: Knowing Knowledge (2006), http : / /www . knowingknowledge.com

5. Kader, B.: Malaysia's Experience in Training Teachers to Use ICT. In: ICT in Teacher Education: Case Studies from the Asia-Pacific Region, pp. 10-22. UNESCO, Bangkok (2008)

6. Won, P.: Bhutan "Support for Teacher Education" Project. In: ICT in Teacher Education: Case Studies from the Asia-Pacific Region, pp. 3-9. UNESCO, Bangkok (2008)

7. Mason, R.: The university: current challenges and opportunities. In: D'Antoni, S. (ed.) The Virtual University, pp. 49-69. UNESCO, Paris (2006)

8. Siemens, G.: The art of blogging. Elearnspace: Everything elearning (2002), http: / /www. connecivism.ca/about

9. Carvalho, A.A., Aguiar, C., Carvalho, C.J., Cabecinhas, R.: Influence of Podcasts Characteristics on Higher Students' Acceptance. In: Bonk, C.J., Lee, M.M., Reynolds, T.H. (eds.) Proceedings of E-Learn, pp. 3625-3633. AACE, Chesapeake (2008)

10. Carvalho, A.A., Aguiar, C., Maciel, R.: A Taxonomy of Podcasts and its Application to Higher Education. In: Damis, H., Creanor, L. (eds.) ALT-C - Conference Proceedings, pp. 132-140. ALT (2009)

11. Salmon, G., Nie, M., Edirisingha, P.: Informal Mobile Podcasting And Learning Adaptation (IMPALA). e-Learning Research Project Report 06/07, University of Leicester (2007)

12. Frydenberg, M.: Principles and Pedagogy: The Two P's of Podcasting in the Information Technology Classroom. ISECON - EDSIG, vol. 23, pp. 1-10 (2006)

13. Durbridge, N.: Audio cassettes. In: Bates, A.W. (ed.) The Role of Technology in Distance Education, pp. 99-107. Croom Helm, Kent (1984)

14. Carvalho, A.A., Aguiar, C., Santos, H., Oliveira, L., Marques, A., Maciel, R.: Podcasts in Higher Education: Students and Teachers Perspectives. In: Tatnall, A., Jones, A. (eds.) Education and Technology for a Better World, pp. 417-426. Springer, Berlin (2009)

15. Levine, A.: Rip. Mix. Learn...The digital generation, social technologies, and learning. A presentation for the Training Expo Partners Conference, September 23 (2004), http://graphite.mcli.dist.maricopa.edu/emerging/wiki?RipMixL earn

16. Carvalho, A.A., Lustigova, Z., Lustig, F.: Integrating new technologies into blended learning environments. In: Stacey, E., Gerbic, P. (eds.) Effective Blended Learning Practices: Evidence-Based in Perspectives in ICT-Facilitated Education, pp. 79-104. IGI Global, Hershey (2009) 
17. Prensky, M.: H. Sapiens Digital: From Digital Immigrants and Digital Natives to Digital Wisdom. Innovate 5(3) (2009), http: / /www. innovateonline.info/index. php?view=article\&id=705

18. Alexander, J.E., Tate, M.A.: Web Wisdom: How to evaluate and create information quality on the Web. Erlbaum, Mahwah (1999)

19. Schrock, K.: Web site evaluation \& Internet lesson plan guide (2002), http: / / kathyschrock.net/abceval/teacherwebeval.pdf

20. Treadwell, M.: 23 Quality Criteria. Teacher@work: internet tools for teachers (2006), http://teachers.work.co.nz/23_criteria.htm

21. Richmond, B.: Ten C's for Evaluating Internet Resources. University of Wiscounsin - Eau Claire, McIntyre Library (2003), http://www. uwec.edu/Library/guides/ tencs.html

22. Jonassen, D.: Modeling with technology: mindtools for conceptual change. Pearson Education, Upper Saddle River (2006)

23. Siemens, G.: Connectivism: A learning theory for the digital age. International Journal of Instructional Technology \& Distance Learning 2 (2005), http://www.itdl.org/ Journal/Jan_05/article01.htm

24. Siemens, G.: New structures and spaces of learning: The systematic Impact of Connectivism, and Networked Learning. In: Carvalho, A.A. (ed.) Actas do Encontro sobre Web 2.0, pp. 7-23, CIEd, Braga (2008)

25. Downes, S.: Seven habits of highly connected people. Elearn Magazine (2008), http: / /www. elearnmag. org/subpage. cfm? section=opinionsarticle $=97-1$

26. John, P.D., Wheeler, S.: Teachers and technology. In: The Digital Classroom: Harnessing Technology for the Future, pp. 15-24. Routldge, London (2008) 